\title{
I.P.M Strategy for Tuta absoluta on Tomatoes and Potatoes
}

\author{
Abdel-Fattah S. A. Saad ${ }^{1}$, EL-Sayed H. M. Tayeb ${ }^{1}$, Abdel-Naser T. Hassan ${ }^{2}$ and Hoda G. A. I. Attia ${ }^{3}$
}

\section{ABSTRACT}

Complementary strategies of pest management aiming to reduce the use of insecticides on Tuta absoluta infested tomatoes and potatoes carried out at Abo hommus during 2017 and 2018 seasons.

Ten of generations of Tuta absoluta were recorded per year. The longest generation period was on January while the shortest generation was on May.

On the other hand the percent infestation by Tuta absoluta was highest on tomatoes than potatoes. The pesticide consequence model indicated that (Emamectin benzoate - Chlorantraniliprole - Flubendiamide Chlorfenapyr) gave the highest percent reduction of Tuta absoluta on the fourth model in the first season of 2017. While, (Chlorantraniliprole - Emamectin benzoate Chlorfenapyr - Flubendiamide) gave the highest pest mean reduction on the third model in the second season of 2018. Flubendiamide followed by Chlorfenapyr gave the highest percent reduction of Tuta absuluta.

Using pheromone traps (E3Z8Z11-14Ac $\left.{ }^{\circledR}\right)$ to monitoring and capturing of Tuta absoluta males in the cultivated field of tomato and potato during 2017 and 2018 seasons, which show that infestation was fluctuated due to the different parameters at field condition.

Key Words: Tomato leafminer, Tuta absoluta, pheromone traps, pesticide consequence model

\section{INTRODUCTION}

The tomato borer, Tuta absoluta (Meyrick) (Lepidoptera: Gelechiidae) has been recognized in South America, then spreading quickly to the major tomato-producing countries. Although the cultural control methods were attempted against $T$. absoluta, using of resistant tomato varieties and the use of pheromones and natural enemies, and insecticides which are still the main control method used, (Guedes and Picanco, 2012).

Nowadays, T. absoluta is present in many countries (Europe, Africa, Middle East and Asia) and affecting nearly $60 \%$ of all cultivated tomato worldwide (Campos et al. 2017, Sylla et al. 2017 and Biondi et al. 2018). The caterpillar feeds on several parts of tomato plants, such as leaves, stems and fruits, causing direct and indirect damage that could result in $100 \%$ yield loss if no control measures are implemented (Desneux et al. 2010 and Tropea Garzia et al. 2012).
Egypt is one of the world's developing countries that suffer from population increase, tomato, (Solanum lycopersicum $\mathrm{L}$.) is considered as the most economically important feeding crop. More than one million fedan are yearly cultivated with tomato varieties for local consumption and export affairs.

T. absoluta attack green plant foliage causing blotch mines between both leaf surfaces, flowers and tend to infest fruits which lead to partial and complete tuber rotting by subsequent insect pest infestations. In this case, the infested fruits become completely un marketable and not suitable for human feeding. Tomato of Autumn plantation is harvested during end of August to early September demonstrating were harbor the highest levels of infestation expressed as number of larvae/plant foliage reliable yield figures (Saad, 2014).

Therefore, the aim of the present study focused on this insect pest Tuta absoluta that attacking tomato and potato in the field at different time of cultivation concerning. In addition using sex pheromone $\left(\mathrm{E} 3 \mathrm{Z} 8 \mathrm{Z11}-14 \mathrm{Ac}^{\circledR}\right)$ as a trail to calculate number of infestation during cultivation period of tomato and potato plants. Also, put an IPM trail to control infestation by using different way of control.

\section{MATERIALS AND METHODS}

Field experiments were carried out during 2017 and 2018 growing seasons at El-Berka village, Abou Hommos city, Behaira province, Egypt. The first field trial was conducted using different sequence of application as a model to control Tuta absoluta without producing resistance strain after application. The second field trial was carried out to estimate the effect of temperature and relative humidity on infestation of the tomato leafminer in tomato and potato. The third field trial was conducted to determine the generations' number of. Tuta absoluta per year under normal conditions.

The experiment was excited in randomized complete blocks design within three replications. The tomato varity namely; Malika F1 was cultivated in both seasons. The plot size was $21 \mathrm{~m}^{2}(1 / 200$ fed-1), with 6 $\mathrm{m}$ in length and $3.5 \mathrm{~m}$ width i.e.; six ridges. All other agricultural practices were applied at the

DOI: : 10.21608/ASEJAIQJSAE.2020.101411

${ }^{1}$ Plant Protection Dept., Faculty of Agric. (Saba Basha), Alex. Univ., Egypt.

${ }^{2}$ Plant Protection Research Institute, Agric. Res. Center, Giza, Egypt.

${ }^{3}$ Plant Protection Research Institute, Agric. Res. Center, El-Sabahia, Alexandria, Egypt.

Received, June 2, 2020, Accepted, , June 29, 2020. 
recommendations of the Egyptian Ministry of Agriculture.

Sampling technique and inspection of the Tuta absoluta

The infestation rate was recorded after 1,5 and 10 days post- spraying taking into account the mean number of larvae / 10 sampled plants /replicate in each treatment compared the check untreated. Percent reductions of infestation were also calculated. The estimated infestation rate in treatments was determined pre- and after 1,5 and 10 days from insecticidal applications and the percent of infestation reduction were calculated using Henderson and Tilton (1955) equation.

Sex pheromone traps for monitoring and capturing the males of the tomato leafminer, Tuta absoluta

Three yellow aquatic pheromone traps (E3Z8Z11$14 \mathrm{Ac}^{\circledR}$ ) were replaced within a cultivated area of Feddan during 2017 and 2018 seasons. The used pheromone traps (1 lure) is specific for $T$. absoluta. Monitoring was started when the plants were 40 days old. Examination was done weekly till the end of the season but the replace every month with another phenomenon. The captured males were counted (Attygalle et al., 1996).

\section{Calculation of generation}

Number of $T$. absoluta per a year calculated according to Richmond et al. (1983) by using lower threshold temperature $\left(\mathrm{T}_{0}\right) 8{ }^{\circ} \mathrm{C}$ with 460 -degree day's unit (D.D.U) for estimating the possible number of generation per year in the field according to the following two formulas:

First if $\mathrm{T}_{\text {min }}$ is lower than $\left(\mathrm{T}_{0}\right) 8^{\circ} \mathrm{C}$

$$
\mathrm{DDU}=\frac{\left(\mathrm{T}_{\max }-\mathrm{T}_{0}\right)^{2}}{2\left(\mathrm{~T}_{\max }-\mathrm{T}_{\min }\right)}
$$

Second $\mathrm{T}_{\min }$ is higher than $\left(\mathrm{T}_{0}\right) 8{ }^{\circ} \mathrm{C}$ using the following equation

$$
\mathrm{DDU}=\frac{\left(\mathrm{T}_{\max }+\mathrm{T}_{\min }\right)}{2}-\mathrm{T}_{0}
$$

\section{Data analysis:}

Pheromone data were analyzed by using a standard analysis method established by SAS institute by (Anonymous, 2003).

\section{Statistical analysis}

All collected data were subjected to the statistical analysis following the procedure described by Gomez and Gomez (1984). The least significantly differenced test (L.S.D) at 0.05 was used to compare between means of the different treatments.

\section{RESULTS AND DISCUSSION}

Agrochemical performance of different adopted models tested chemical insecticides against the tomato leafminer, Tuta absoluta infesting tomato plants on 2017 season

The data in Table 1 shows the efficiency of the tested insecticides through the different adopted models against the insect-pest compared to the untreated check.

The presented data of $1^{\text {st }}$ model proved statistically that there were significant differences regarding the general mean for reduction percent among the tested treatments. In this context, the highest general mean of reduction resulted from Chlorantraniliprole $70.70 \%$ and Flubendiamide $60.94 \%$. Meanwhile both of Chlorfenapyr and Emamectin benzoate gave reduced values of reduction comprised 54.43 and $53.12 \%$ in respects.

In general, $2^{\text {nd }}$ model showed that both Chlorfenapyr and Flubendiamide recorded the highest general means of 88.16 and 80.97 of reduction percent, respectively. The less effective one was Chlorantraniliprole and Emamectin benzoate with a reduction percent of (74.63\%), for each.

On the third model of 2017, the same trend were revealed that highest general means of reduction percent $(89.73 \%)$ obtained by Flubendiamide, followed by $(88.26 \%)$ for Emamectin benzoate and Chlorfenapyr with (84.59\%) a reduction, in respect, but Chlorantraniliprole gave less effective with $82.61 \%$ reduction percent.

The fourth model on 2017, the data indicated that Flubendiamide was the most effective treatment causing 98.42\% reduction, followed by Chlorfenapyr with reduction percent $96.32 \%$, while Emamectin benzoate and Chlorantraniliprole gave less effective with $88.66 \%$ and $86.57 \%$ reduction percent against the tomato leafminer, Tuta absoluta infesting tomato plants, successfully.

Agrochemical performance for different adopted models against the tomato leafminer, Tuta absoluta infesting tomato plants on 2018 season

The tested treatments for the first model gave the general means reduction percent of $77.14 \%$ for both Chlorantraniliprole and Chlorfenapyr. While both treatment of Emamectin benzoate and Flubendiamide gave reduction values comprised to $67.34 \%$ and $65.04 \%$ in respects. 
Table 1. Agrochemicals performance means for the pesticides model on tomato leafminer, Tuta absoluta infesting tomato plants in 2017 season

\begin{tabular}{|c|c|c|c|c|c|c|c|c|c|c|c|}
\hline \multicolumn{12}{|c|}{$1^{\text {st }}$ season $(2017)$} \\
\hline $1^{\text {st }}$ model & A & B & $2^{\text {nd }}$ model & $\mathbf{A}$ & B & $3^{\text {rd }}$ model & $\mathbf{A}$ & $\mathbf{B}$ & $4^{\text {th }}$ model & $\mathbf{A}$ & B \\
\hline Flubendiamide & 4.66 & 60.94 & Chlorfenapyr & 2.33 & 88.16 & Chlorantraniliprole & 3.66 & 82.61 & $\begin{array}{l}\text { Emamectin } \\
\text { benzoate }\end{array}$ & 2.11 & 88.66 \\
\hline Chlorfenapyr & 3.50 & 54.43 & Flubendiamide & 2.00 & 80.97 & $\begin{array}{l}\text { Emamectin } \\
\text { benzoate }\end{array}$ & 1.33 & 88.26 & Chlorantraniliprole & 2.66 & 86.57 \\
\hline $\begin{array}{l}\text { Emamectin } \\
\text { benzoate }\end{array}$ & 2.00 & 53.12 & Chlorantraniliprole & 1.66 & 74.63 & Chlorfenapyr & 1.00 & 84.59 & Flubendiamide & 0.33 & 98.42 \\
\hline Chlorantraniliprole & 1.00 & 70.70 & $\begin{array}{l}\text { Emamectin } \\
\text { benzoate }\end{array}$ & 1.33 & 74.63 & Flubendiamide & 0.33 & 89.73 & Chlorfenapyr & 0.77 & 96.32 \\
\hline Untreated check & 21.33 & - & Untreated check & 22.33 & - & Untreated check & 24.33 & - & Untreated check & 22.33 & - \\
\hline
\end{tabular}

$\mathrm{A}=$ Average number of larvae $/ 10$ plants

$\mathrm{B}=$ Reduction percent $(\%)$

The second model showed that Chlorfenapyr was the most effective treatment causing $87.98 \%$ reduction, followed by Flubendiamide with reduction percent $84.38 \%$, while Chlorantraniliprole and Emamectin benzoate gave less effective with reduction percent 84.14 and $74.63 \%$ for each, successfully.

The data presented in the third model on Table (2) indicated that Emamectin benzoate and Flubendiamide were the most effective treatments causing $91.78 \%$ a reduction, for each, but Chlorfenapyr and Chlorantraniliprole gave less effective with reduction percent $89.43 \%$ and $84.93 \%$ reduction, in respectively.

The fourth model indicated that Flubendiamide was the most effective treatment causing $90.50 \%$ reduction, followed by Chlorantraniliprole with reduction percent 86.36\%, while Emamectin benzoate and Chlorfenapyr gave less effective reduction percent $85.33 \%$ and $83.11 \%$, in respectively.

The above demonstrated results were in agreement with those mentioned earlier investigators for example, Bassi et al. (2012) when reported that Chlorantraniliprole (Rynaxypyr ${ }^{\circledR}, \quad$ Coragen $\AA$ and Altacor $\AA$ ) gave outstanding performance against Tuta absoluta with extremely low mammalian toxicity profile. This compound was tested on T. absoluta since 2002 in Brasil and the early results indicated a new standard of T. absoluta control, even on insecticide-resistant populations. Nannini et al. (2012) reported that the most insecticides used in Sardinian tomato greenhouses by growers against $T$. absoluta management were initially abamectin, azadirachtin and spinosad.

Table 2. Agrochemicals performance means for the pesticides models on tomato leafminer, Tuta absoluta infesting tomato plants in 2018 season

\begin{tabular}{|c|c|c|c|c|c|c|c|c|c|c|c|}
\hline \multicolumn{12}{|c|}{$1^{\text {st }}$ season $(2017)$} \\
\hline $1^{\text {st }}$ model & $\mathbf{A}$ & B & $2^{\text {nd }}$ model & $\mathbf{A}$ & $\mathbf{B}$ & $3^{\text {rd }}$ model & $\mathbf{A}$ & B & $4^{\text {th }}$ model & $\mathbf{A}$ & B \\
\hline Flubendiamide & 4.33 & 65.04 & Chlorfenapyr & 3.00 & 87.98 & Chlorantraniliprole & 3.67 & 84.93 & Emamectin benzoate & 3.66 & 85.33 \\
\hline Chlorfenapyr & 2.00 & 77.14 & Flubendiamide & 2.67 & 84.38 & Emamectin benzoate & 1.33 & 91.78 & Chlorantraniliprole & 2.33 & 86.36 \\
\hline Emamectin benzoate & 1.66 & 67.34 & Chlorantraniliprole & 1.67 & 84.14 & Chlorfenapyr & 1.00 & 89.43 & Flubendiamide & 1.00 & 90.50 \\
\hline Chlorantraniliprole & 0.66 & 77.14 & Emamectin benzoate & 1.33 & 74.63 & Flubendiamide & 0.33 & 91.78 & Chlorfenapyr & 0.66 & 83.11 \\
\hline Untreated check & 11.66 & - & Untreated check & 22.33 & - & Untreated check & 24.33 & - & Untreated check & 25.00 & - \\
\hline
\end{tabular}

$\mathrm{A}=$ Average number of larvae $/ 10$ plants

$\mathrm{B}=$ Reduction percent $(\%)$ 


\section{Sex pheromone traps for capturing the tomato leafminer}

Virgin female tomato leafminer releases a sex pheromone that strongly attracts males (Quiroz, 1978). This pheromone was identified by Attygalle et al., (1996) as (3E, 8Z, 11Z)-3,8,11-tetradecatrien-1-xyl acetate. By monitoring T. absoluta males using pheromone traps, it may be possible to determine the correct timing for insecticide applications leading to a reduction and proper rational use of pesticides. Therefore the complementary strategies for pest management aiming to reduce the use of insecticides through an efficient monitoring of pest population to fix a correct time for pesticide application need to be tested including the use of pheromone. Taha et al. (2014) reported that $T$. absoluta sex pheromone appears to be a valuable component in the integrated management of $T$. absoluta.

The date of male captures by pheromone traps that have been set inside the tomato and potato fields were weekly monitored to evaluate their efficiency in capturing the tomato insect-pest Tuta absoluta.

Pheromone traps were set to assess the population of Tuta absoluta during either the spring season of tomato plantation but the winter and Neely seasons of potato plantation. Examination of the traps was carried out at intervals of 7 days and therefore, the number of adults caught by pheromone traps every week was recorded and identified.

The date showed the seasonal fluctuations of Tuta absoluta on tomato plants during the first season of 2017, began to occur during the period elapsed from transplanting until early harvest on tomato plants.
The first appearance was 56.52 male / 3 traps on the $1^{\text {st }}$ week. One peak was noticed on the $5^{\text {th }}$ week, 2017 with a mean number of 103.44 male / 3 traps, where it was the lowest peak. The second peak occurred on the $12^{\text {th }}$ week with a mean number of 155.38 male / 3 traps. This means that in the first season, Tuta absoluta had two population peaks. (Fig. 1).

The data showed the seasonal fluctuations of Tuta absoluta on tomato plants during the second season of 2018; in the sense that the Tuta absoluta male began to occur during the period elapsed from transplanting until early harvest on tomato plants. The first appearance was 9.95 male / 3 traps on the $1^{\text {st }}$ week. One peak was noticed on the $10^{\text {th }}$ week, 2018 with a mean number of 103.94 male / 3 traps, where it was the highest peak. The second peak occurred on the $17^{\text {th }}$ week with a highest number of 88.71 male / 3 traps. This demonstration that in the second season, Tuta absoluta had two population peaks. (Fig. 2).

The date showed the seasonal fluctuations of Tuta absoluta on potato plants during the first season of 2017; in the sense, which Tuta absoluta larvae began to occur during the period elapsed from transplanting until early harvest on potato plants. The first appearance was 16.86 male / 3 traps on the $1^{\text {st }}$ week. One peak was noticed on the $9^{\text {th }}$ week, 2017 with a mean number of 110.68 male / 3 traps, where it was the lowest peak. The second peak occurred on the $14^{\text {th }}$ week with a mean number of 105.03 male / 3 traps. This means that in the first season, Tuta absoluta had two population peaks. (and Fig. 3).

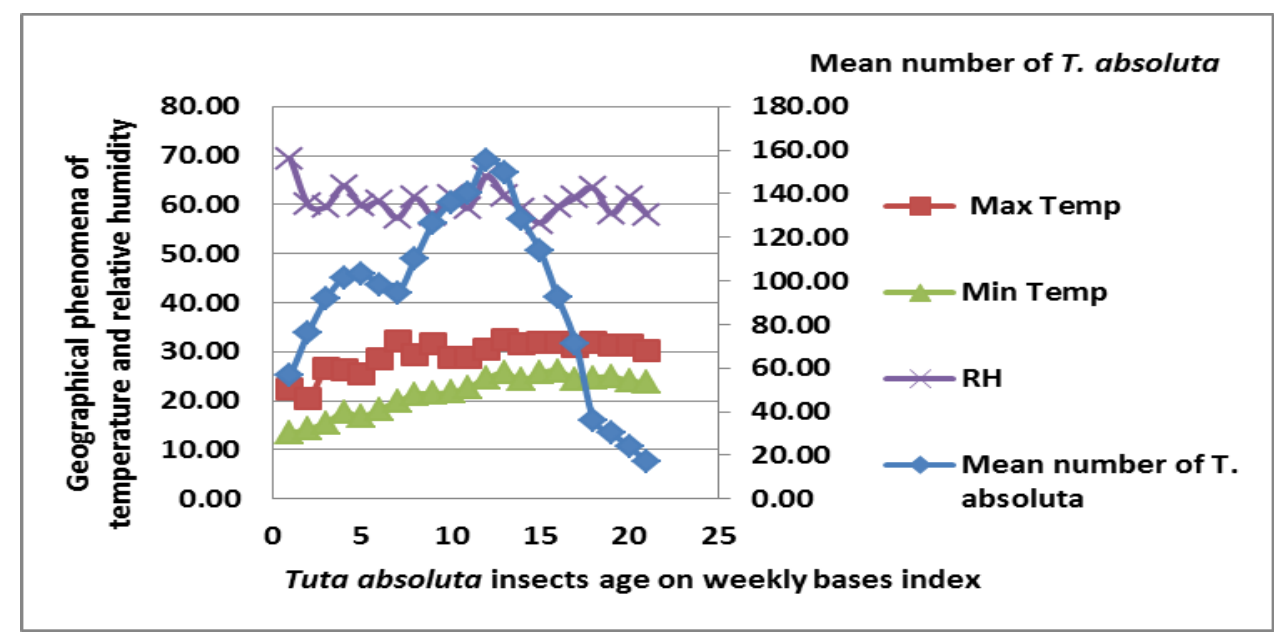

Fig. 1. Relationship between the different weather factors (Temperature and Humidity) and Tuta absoluta infestation level though plant age on tomato traps during 2017 season 


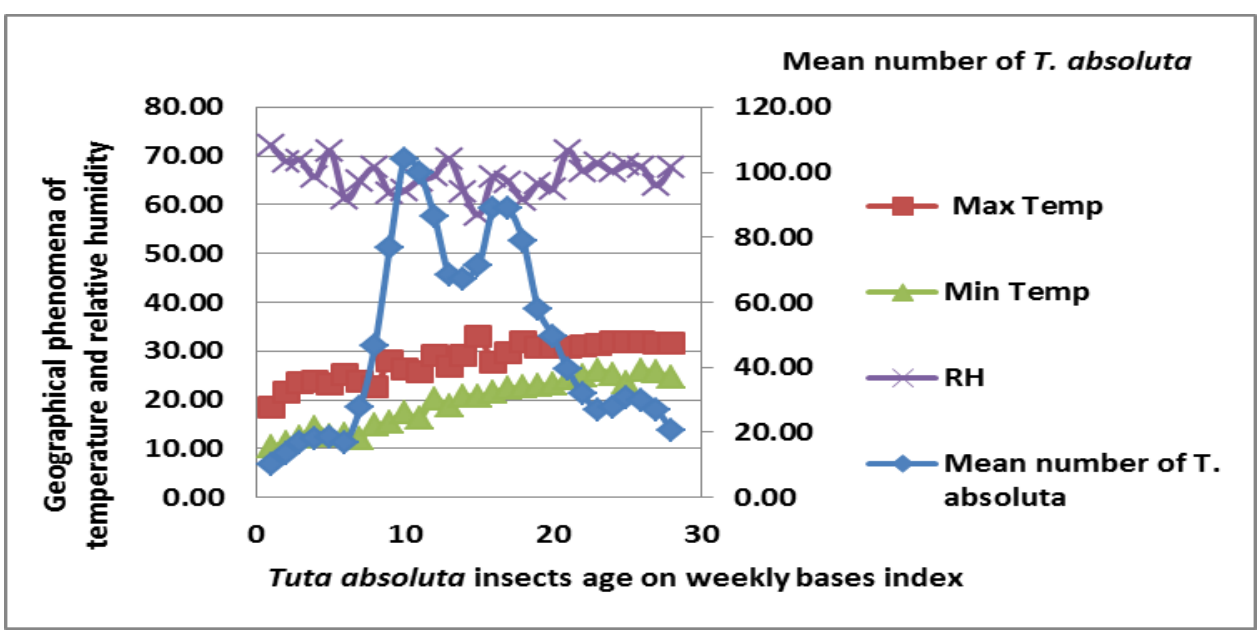

Fig. 2. Relationship between the different weather factors (Temperature and Humidity) and Tuta absoluta infestation level though plant age on tomato traps during 2018 season

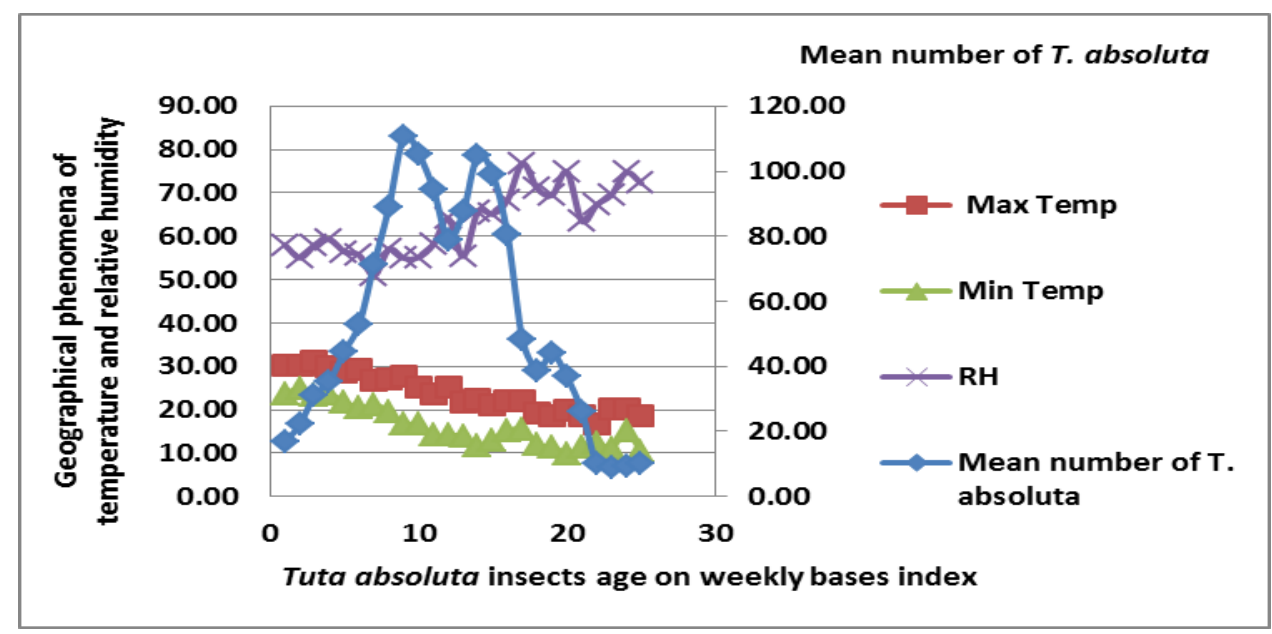

Fig. 3. Relationship between the different weather factors (Temperature and Humidity) and Tuta absoluta infestation level though plant age on potato traps during 2017 season

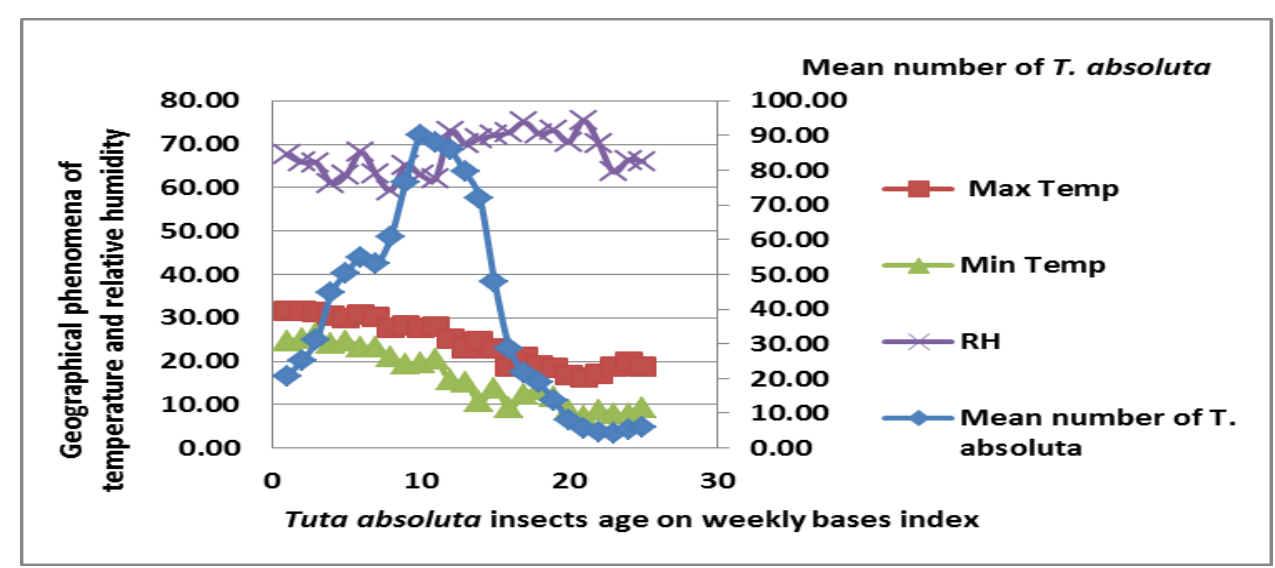

Fig. 4. Relationship between the different weather factors (Temperature and Humidity) and Tuta absoluta infestation level though plant age on potato traps during 2018season 


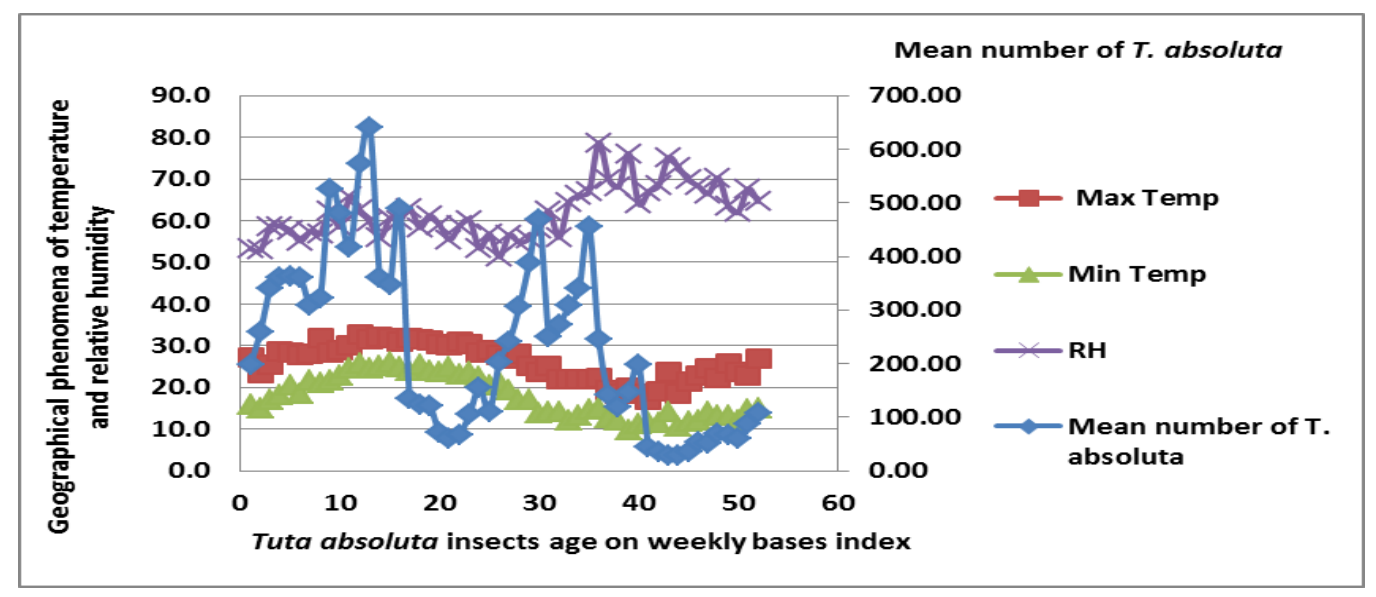

Fig. 5. Correlation of infestation by Tuta absoluta for tomatoes and potatoes during the year 2017

The data showed the seasonal fluctuations of Tuta absoluta on potato plants during the second season of 2018; in the sense, which Tuta absoluta larvae began to occur during the period elapsed from transplanting until early harvest on tomato plants. The first appearance was 20.67 male / 3 traps on the $1^{\text {st }}$ week. One peak was noticed on the $6^{\text {th }}$ week, 2018 with a mean number of 55.03 male / 3 traps, where it was the lowest peak. The second peak occurred on the $10^{\text {th }}$ week with a highest number of 90.13 male / 3 traps. This means that in the second season, Tuta absoluta had two population peaks. (Fig. 4)

The above demonstrated results were in agreement with those mentioned by earlier investigators for example; Nunez et al. (2009) used sex pheromones successfully to control $T$. absoluta. The goal of his study was to evaluate the effect of sex pheromones on male behavior in greenhouse conditions. The first step was to determine the durability of male attraction to rubber septa dispensers loaded with $0.2 \mathrm{mg}$ of the pheromone, which according to our results can be estimated to last for at least 105 days. Then, the effect of sex pheromones on male behavior was evaluated. Male captures in traps baited either with pheromone septa or virgin females were used as indicators for the efficacy of the treatments. Two dispenser densities (16.000 and 32.000 per hectare), with and without a sticky surface as a mortality factor, were evaluated. The sticky surface did not improved effectively. Finally, 3.200 dispensers were located in a $1000 \mathrm{~m}^{2}$ commercial greenhouse, resulting in a strong reduction of male captures with respect to an untreated greenhouse that served as control and reduction of trap captures were more than $96 \%$ for the first 78 days after dispenser installation, falling to $92 \%$ at 106 days. These results showed that sex pheromone of $T$. absoluta affects male behavior and could be an important tool to control this pest. Hrnčic and Radonjic (2011) detected the arrival $T$. absoluta by setting up pheromone traps in greenhouses, at four locations. The first captured moths were found in the middle of July in one locality at the coast. In the period from the last week of July to the first week of August, large galleries in tomato leaves, green and ripe fruits were detected at all four monitored locations, as well as at some other sites. The same symptoms as those on tomato were detected on leaves of Solanum nigrum, which as a weed, is usually present around and inside greenhouses. In Egypt Mahmoud et al., (2015) found that, T. absoluta had four peaks during winter season; the first peak occurred in the 4th week of Jan., the second occurred in the 3rd week of February, the third was in 3rd week of March, while the fourth occurred in the 1st week of April. In summer plantations, four peaks of $T$. absoluta were recorded the first peak was in 2 nd week of July, the second was in 1st week of August, the third and fourth were in the 1st and the 4th week of Sept., respectively.

\section{Generation number of the tomato leafminer, Tuta absoluta Meyrick on tomato and potato}

The tomato leafminer, Tuta absoluta Meyrick had 10 generations in both season of 2017 and 2018, and the longest period for a generation occurred in the first generation in January while the shortest generation was the fifth generation during May 2017 and sixth, seventh and eighth generations during June, July and August 2018. (Tables, 3 and 4) 
Table 3. Generation number of Tuta absoluta Meyrick during 2017 season

\begin{tabular}{ccccc}
\hline Generation & Start & End & Duration in days & Accumulated heat units \\
\hline $1^{\text {st }}$ & $1 / 1 / 2017$ & $3 / 17 / 2017$ & 75 & 461.95 \\
$2^{\text {nd }}$ & $3 / 18 / 2017$ & $4 / 29 / 2017$ & 42 & 461.88 \\
$3^{\text {rd }}$ & $4 / 30 / 2017$ & $5 / 30 / 2017$ & 30 & 469.22 \\
$4^{\text {th }}$ & $5 / 31 / 2017$ & $6 / 27 / 2017$ & 27 & 475.67 \\
$5^{\text {th }}$ & $6 / 28 / 2017$ & $7 / 19 / 2017$ & 21 & 472.39 \\
$6^{\text {th }}$ & $7 / 20 / 2017$ & $8 / 11 / 2017$ & 22 & 464.61 \\
$7^{\text {th }}$ & $8 / 12 / 2017$ & $9 / 4 / 2017$ & 23 & 473.56 \\
$8^{\text {th }}$ & $9 / 5 / 2017$ & $9 / 29 / 2017$ & 24 & 470.83 \\
$9^{\text {th }}$ & $9 / 30 / 2017$ & $10 / 28 / 2017$ & 28 & 460.22 \\
$10^{\text {th }}$ & $10 / 29 / 2017$ & $12 / 11 / 2017$ & 43 & 464.11 \\
$11^{\text {th }}$ & $12 / 12 / 2017$ & not completed & & \\
\hline
\end{tabular}

Table 4. Generation number of Tuta absoluta Meyrick during 2018 season

\begin{tabular}{ccccc}
\hline Generation & Start & End & Duration in days & Accumulated heat units \\
\hline $1^{\text {st }}$ & $1 / 1 / 2018$ & $3 / 2 / 2018$ & 60 & 467.30 \\
$2^{\text {nd }}$ & $3 / 3 / 2018$ & $4 / 13 / 2018$ & 41 & 460.39 \\
$3^{\text {rd }}$ & $4 / 14 / 2018$ & $5 / 15 / 2018$ & 31 & 465.94 \\
$4^{\text {th }}$ & $5 / 16 / 2018$ & $6 / 10 / 2018$ & 25 & 463.11 \\
$5^{\text {th }}$ & $6 / 11 / 2018$ & $7 / 5 / 2018$ & 24 & 471.39 \\
$6^{\text {th }}$ & $7 / 6 / 2018$ & $7 / 28 / 2018$ & 22 & 469.89 \\
$7^{\text {th }}$ & $7 / 29 / 2018$ & $8 / 20 / 2018$ & 22 & 474.06 \\
$8^{\text {th }}$ & $8 / 21 / 2018$ & $9 / 12 / 2018$ & 22 & 469.06 \\
$9^{\text {th }}$ & $9 / 13 / 2018$ & $10 / 7 / 2018$ & 24 & 465.50 \\
$10^{\text {th }}$ & $10 / 8 / 2018$ & $11 / 5 / 2018$ & 28 & \\
$11^{\text {th }}$ & $11 / 6 / 2018$ & not completed & & \\
\hline
\end{tabular}

\section{CONCLUSIONS}

It could be concluded that application of using sex pheromone traps to find out the population fluctuations for Tuta absoluta on tomato and potato plants to find out the appropriate time to use chemical control. Also, using the recommended pesticides from time of begin transplants up to time of begin harvest against Tuta absoluta on tomato and potato plants to give on optimizing tomato and potato yield and decrease costs and environmental pollution.

\section{REFERENCES}

Anonymous. 2003. SAS Statistics and graphics guide, release 9.1. SAS Institute, Cary, North Carolina 27513. USA.

Attygalle, A. B., G. N. Jham, A. Svatǒs, R. T. S. Friguetto, F. A. Ferrara, E. F. Vilela, M. A. Uchôa-Fernandez and J. Meinwald. 1996. (3E, 8Z, 11Z)-3,8,11-tetradecatrienyl acetate, major sex-pheromone component of tomato pest, Scrobipalpuloides absoluta (Lepidoptera: Gelechiidae). Biorg. Med. Chem. 4: 305-314.
Barrientos, Z. R., H. J. Apablaza, S. A. Norer and P.P. Estay. 1998. Threshold temperature and thermal constant for development of the South American tomato moth Tuta absoluta (Meyrick) (Lepidoptera: Olethreutidae).

Bassi, A., J. L. Rison, E. Roditakis and L. Sannino (2012). Chlorantraniliprole (Rynaxypyr $^{\circledR}$, Coragen ${ }^{\circledR}$, Altacor $^{\circledR}$ ) key features for sustainable control of Tuta absoluta. IOBC/WPRS Bulletin. 80: 193-198.

Biondi, A., R.Guedes, F. Wan and N. Desneux. 2018. Ecology, worldwide spread, and management of the invasive South American Tomato Pinworm, Tuta absoluta: Past, present, and future. Annual Review of Entomology 63:239-258. https://doi.org/10. 1146/annurev-ento-031616-034933.

Campos, M. R., A. Biondi, A. Adiga, R. N. C. Guedes and N. Desneux. 2017. From the Western Palaearctic region to beyond: Tuta absoluta 10 years after invading Europe. J. of Pest Sci. 90: 787- 796. https://doi.org/10.1007/s10340017-0867-7. 
Desneux, N., E. Wajnberg, K. A. G. Wyckhuys, G. Burgio, S. Arpaia, C. A. Narváez-Vasquez, J. González-Cabrera, D. C. Ruescas, E. Tabone, J. Frandon, J. Pizzol, C. Poncet, T. Cabello and A. Urbaneja. 2010. Biological invasion of European tomato crops by Tuta absoluta: Ecology, geographic expansion and prospects for biological control. J. of Pest Sci. 83: 197-215. https://doi.org/10.1007/s10340-010-0321-6.

Gomez, K. N. and A. A. Gomez. 1984. Statistical procedures for agricultural research. John Wiley and Sons, New York, 2nd ed., $68 \mathrm{P}$.

Guedes, R. N. C. and M. C. Picanço. 2012. The tomato borer Tuta absoluta in South America: Pest status, management and insecticide resistance. EPPO Bulletin. 42(2):211-216. https://doi.org/10.1111/epp.2557.

Henderson, C. F. and E. W.Tilton. 1955. Tests with acaricides against the brown wheat mite. J. Econ. Entomol. 48: 157161.

Hrnčic', S. and S. Radonjic'. 2011. Tuta absoluta Meyrick (Lepidoptera, Gelechiidae), a new pest in Montenegro. IOBC/WPRS Bulletin. 68: 71-74.

Mahmoud, Y. A., I. M. A. Ebadah, A. S. Abd-Elrazek, T. E. Abd-Elwahab. and S. H. D. Masry. 2015. Population fluctuation of tomato leafminer, Tuta absoluta (Meyrick) (Lepidoptera: Gelechiidae) during winter and summer plantations in Egypt. Research J. of Pharmaceutical, Biological and Chemical Sci. 6:647-652.

Nannini, M., F. Atzori, M. Coinu, R. Pisci and F. Sanna. 2012. A three-year survey of Tuta absoluta (Lepidoptera: Gelechiidae) population trends in Sardinian tomato greenhouses. IOBC/WPRS Bulletin. 80: 39-44.
Nunez, P., A. Zignago, J. Paullier and S. Nunez. 2009. Sex pheromones to control tomato moth Tuta absoluta (Meyrick) (Lep., Gelechiidae). Agrociencia (Montevideo). 13(1): 27-35.

Quiroz, C. 1978. Utilizacion de trampas con hembras virgines de Scrobipalputa absoluta (Meyrick) (Lepidoptera: Gelechiidae) en studios di dinámica de población. Agric. Tech. 38: 94-97.

Richmond, J. A., H. A. Thomas and H. B. Hattachargya. 1983. Predicting spring flight of Nantucket pine tip moth (Lepidoptera: Olethreutidae) by heat unit accumulation. J. of Economic Entomology. 76: 269-271.

Saad, A.S.A., E. H. M. Tayb, Leila M. Abdel-Nabi, Hoda G. A. I. Attia. 2014. Integrated pest management for Tuta absoluta (Lepidoptera: Gelechiidae) infesting tomato plants in Egypt. J. Adv. Agric. Res. (Fac. Agric Saba Basha). 29(4): 756-767.

Sylla, S., T. Brévault, A. B. Bal, A. Chailleux, M. Diatte, N. Desneux and K. Diarra. 2017. Rapid spread of the tomato leafminer, Tuta absoluta (Lepidoptera: Gelechiidae), an invasive pest in SubSaharan Africa. Entomologia Generalis. 36:269-283. https://doi.org/10.1127/entomologia/2017/0453.

Taha, A. M., A. F. E. Afsah and F. H. Fargalla. 2014. Evaluation of the effect of integrated control of tomato leafminer,Tuta absoluta with sex pheromone and insecticides. Nature Sci. 11(7): 26-29.

Tropea Garzia, G., G. Siscaro, A. Biondi and L. Zappalà. 2012. Tuta absoluta a South American pest of tomato now in the EPPO region: biology, distribution and damage. EPPO Bulletin. 42: 205-210. https://doi.org/10.1111/epp.2556. 


\section{الملخص العربي}

إستراتيجية المكافحة المتكاملة للآفات لصانعة أنفاق أورلق الطماطم على الطماطم والبطاطس

عبد الفتاح سيد عبدالكريم سعد، السيد حسن محمد تايب، عبدالناصر توفيق حسن و هدى جابر عبدالسلام إبراهيم عطية

كما تم تسجيل عدد 10 أجيال في السنة وأطول مدة جيل كانت فى شهر يناير خلال العامين وأقصر مدة جيل فيل كانت

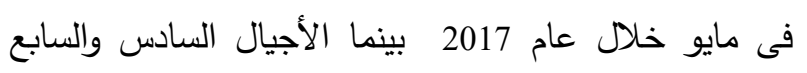

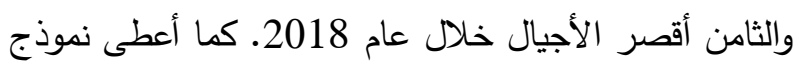

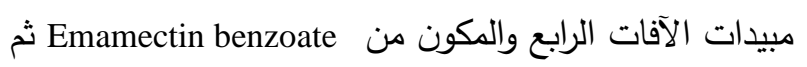
Chlorfenapyr ثما ثم Chlorantraniliprole أعلى نسبة إنخفاض للتوتا فى الموسم الأول 2017 بينما

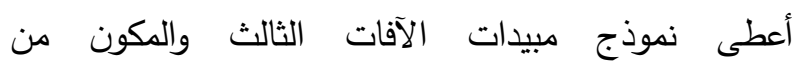
ث Emamectin benzoate ث Chlorantraniliprole Chlorfenapyr للتوتا فى الموسم الثانى 2018.
تهدف الإدارة المتكاملة لدكافحة الآفات إلى الحد من

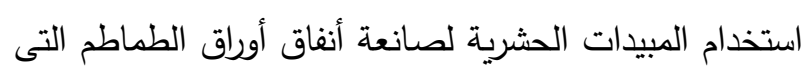
تصيب الطماطم والبطاطاس في منطقة أبو حمص خلال

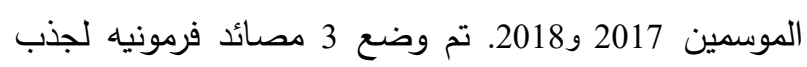
الذكور • بدأ الرصد عندما كان عمر النبات 40 يوم وتم إجراء الفحص أسبوعياً حتى نهاية الموسم وتسجيل عدد الذكور الندات الذين تم اصطيادهم وتم دراسة العلاقة بين الظواهر الجوية التهية (درجه الحراره - الرطوبة النسبيه) ونسبة الإصابة بالتوتا أبسليوتا.

أوضحت النتائج أنه كلما زاد عمر النبات كلما زاد تواجد

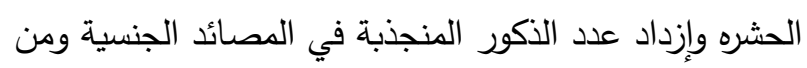

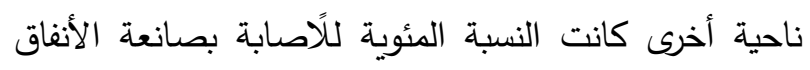
عالية في الطماطم مقارنة بالبطاطس. 